\title{
Cotyledonoid Dissecting Leiomyoma of the Uterus: An Unexpected Diagnosis After Delivery
}

\author{
Leiomioma Cotiledonóide Dissecante do Útero: Um \\ Diagnóstico Inesperado Após o Parto
}

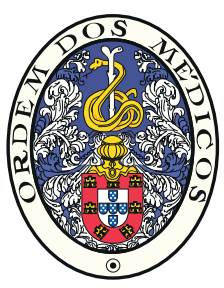

\author{
Ana Carolina ROCHA $\rrbracket^{1}$, Mariline OLIVEIRA ${ }^{1}$, Pedro LUÍS ${ }^{2}$, Madalena NOGUEIRA ${ }^{1}$ \\ Acta Med Port 2018 Apr;31(4):223-227 • https://doi.org/10.20344/amp.8707
}

\begin{abstract}
Cotyledonoid dissecting leiomyoma, also known as Sternberg tumor, is a rare benign uterine tumor with a gross and radiological appearance that may suggest the possibility of a malignancy. We report a case of a thirty-eight-year-old female patient who presented with menorrhagia and abdominal pain one month after delivery by cesarean section. An ultrasound scan showed a heterogeneous pelvic mass, near the isthmic region, with $25 \times 24 \times 23 \mathrm{~mm}$ without vascularization so the possibility of placenta accreta could not be excluded. During hysterectomy, we also removed a small grey mass in the right ovary. Microscopic examination revealed a proliferation of a sparsely cellular tissue with extensive hyalinization and coagulative necrosis, composed of spindle shaped muscle cells without cellular atypia or mitoses. The patient is without evidence of recurrence one year and six months post-surgery.
\end{abstract}

Keywords: Leiomyoma; Postpartum Period; Uterine Neoplasms

\section{RESUMO}

O leiomioma cotiledonóide dissecante, também conhecido como tumor de Sternberg, é uma forma rara de tumor uterino benigno com uma aparência macroscópica e radiológica sugestiva de malignidade. Reportamos o caso de uma doente de trinta e oito anos que se apresentou com menorragia e dor abdominal, um mês após um parto por cesariana. Na ecografia visualizava-se uma massa heterogénea, próxima da região ístmica, com $25 \times 24 \times 23 \mathrm{~mm}$ e sem vascularização, pelo que não foi excluída a possibilidade de placenta acreta. Aquando da histerectomia, foi também excisada uma pequena massa cinzenta do ovário direito. A análise microscópica das peças cirúrgicas, revelou uma proliferação de tecido celular esparso, com extensas áreas de hialinização e necrose coagulativa, compostas por células fusiformes musculares sem atipia ou mitoses. A doente apresenta-se sem evidência de recorrência um ano e meio após a cirurgia.

Palavras-chave: Leiomioma; Neoplasias Uterinas; Período Pós-Parto

\section{INTRODUCTION}

Leiomyomas are the most common benign tumors of the female genital tract. Roth et al, ${ }_{1}^{1}$ in 1996, defined an unusual type of myoma as 'cotyledonoid dissecting myoma'. To the best of our knowledge, approximately 43 cases of this rare variant have been reported in the English language literature. ${ }^{2}$ There are no known risk factors. Due to its macroscopic appearance of a gross exophytic mass resembling placental tissue with extrauterine extensions, it is often misdiagnosed clinically and pathologically. The recognition of this condition as benign will prevent radical hysterectomy and preserve fertility in young female patients. In this report, we describe cotyledonoid dissecting leiomyoma as an incidental finding during the investigation of menorrhagia and abdominal pain after a delivery by cesarean section. This case represents the first one reported presenting after a pregnancy.

\section{CLINICAL CASE}

A previously healthy 38 -year-old woman, gravidity 2 para 2, had a delivery by cesarean section at 36 weeks gestation due to moderate preeclampsia. In the surgery, the placenta was very difficult to remove, demonstrating some degree of adherence. In the immediate postpartum period, the patient had a moderate hemorrhage. The placenta appeared to be complete by analyzing the cotyledons. The pelvic examination was normal. A pelvic ultrasound scan showed a bulky uterus with an irregular and thickened endometrium with an intracavitary mass, near the hysterorrhaphy (horizontal surgical incision in the uterus). During the admission, we used oxytocin and misoprostol to control the hemorrhage. As they were insufficient, we performed a hemostatic curettage to rule out the possibility of retained placenta/membranes. The procedure went without complications. The patient was discharged after five days, hemodynamically stable.

One month later, she presented with menorrhagia and abdominal pain. An ultrasound performed at admission (Figs. $1 \mathrm{~A}$ and $1 \mathrm{~B})$ revealed an enlarged uterus $(111 \times 48$ x $66 \mathrm{~mm})$ with an heterogeneous mass $(25 \times 24 \times 23 \mathrm{~mm})$ near the isthmic region, without vascularization. It also demonstrated an extrauterine mass $(20 \times 7 \mathrm{~mm})$ juxtaposed to the first one, with echogenicity similar to the myometrium, with a moderate blood supply.

Computed tomography (CT) scan showed a $25 \mathrm{~mm}$ soft tissue mass with hypodense regions occupying the anterior wall of the uterus, extending between fascicles of the myometrium adjacent to the dominant mass, with apparent loss of plane of cleavage between the bladder (Fig. 2).

\footnotetext{
1. Serviço de Ginecologia-Obstetrícia. Departamento da Mulher e da Criança. Hospital de Santarém. Santarém. Portugal.

2. Serviço de Anatomia Patológica. Hospital de Santarém. Santarém. Portugal.

$\bowtie$ Autor correspondente: Ana Carolina Rocha. carolinarch14@gmail.com

Recebido: 20 de janeiro de 2017 - Aceite: 23 de fevereiro de 2018 | Copyright @ Ordem dos Médicos 2018
} 


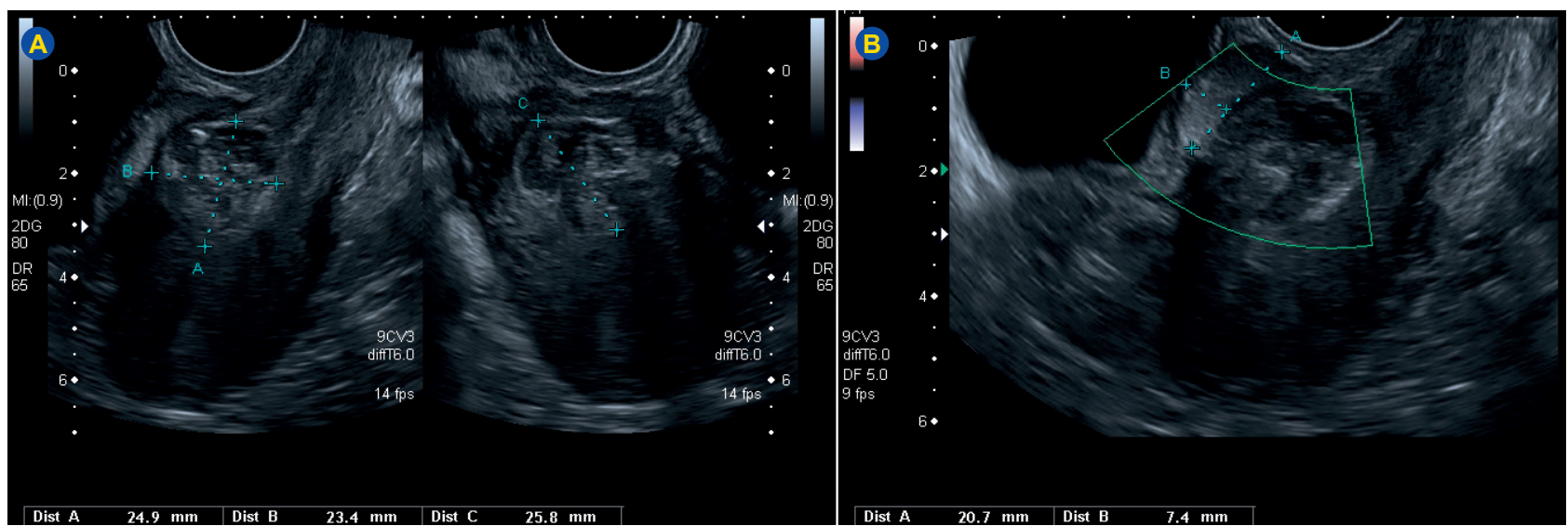

Figure 1 - Ultrasound- A and B: heterogeneous mass near the isthmic region, with echogenicity similar to the myometrium

In the cystoscopy it was found out that there was no vesical invasion.

After discussion with the patient, we performed a total abdominal hysterectomy, bilateral salpingectomy and tumorectomy of the right ovary (a small grey mass with 5 $\mathrm{mm})$.

\section{RESULTS}

The first histological results after the hemostatic curettage showed an intrauterine retention of placental remains with extensive coagulative necrosis.

After the hysterectomy, at macroscopic examination the dimensions on the uterus were $90 \times 50 \times 35 \mathrm{~mm}$ and $66 \mathrm{~g}$ in weight. In the anterior wall of the uterus, a tumor mass with reddish, exophytic, multilobulated placental like gross appearance was observed, with $20 \mathrm{~mm}$ in greater axis, growing towards the serosa (Figs. $3 \mathrm{~A}$ and $3 \mathrm{~B}$ ).

Histological examination showed multilobular prolife- ration of a sparsely cellular hyalinized tissue, dissecting the myometrium and reaching the serosa (Fig. 4A), with foci of granulation tissue (Fig. 4C - arrow) and coagulative necrosis (Fig. 4D); the viable cells showed an absence of mitotic figures or atypia (Fig. 4B - arrows). In the immunohistochemical study, the cells showed strong positivity for smooth muscle actin, desmin and h-caldesmon and negativity for CD10 (Fig. 4), findings compatible with muscle cells. These histological features were in keeping with a diagnosis of dissecting leiomyoma of the uterus, without any morphological features of malignancy.

Moreover the tumor removed from the ovary showed the same microscopic characteristics from the mass in the uterus.

The patient was discharged from the hospital without complications five days following surgery and was healing well without evidence of recurrence, one year and half after the surgery.

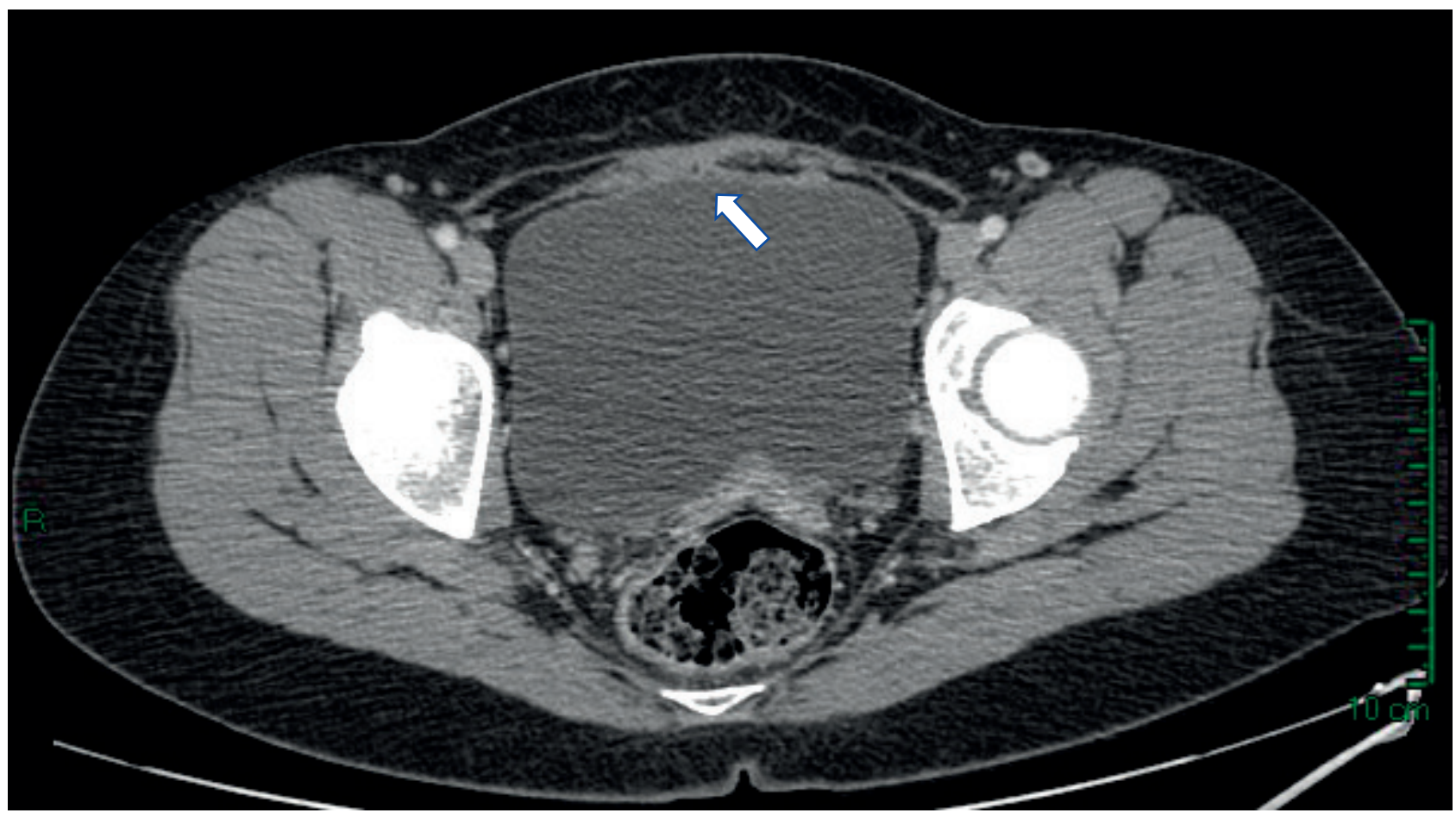

Figure 2 - Computed tomography: hypodense regions occupying the anterior wall of the uterus (white arrow) 

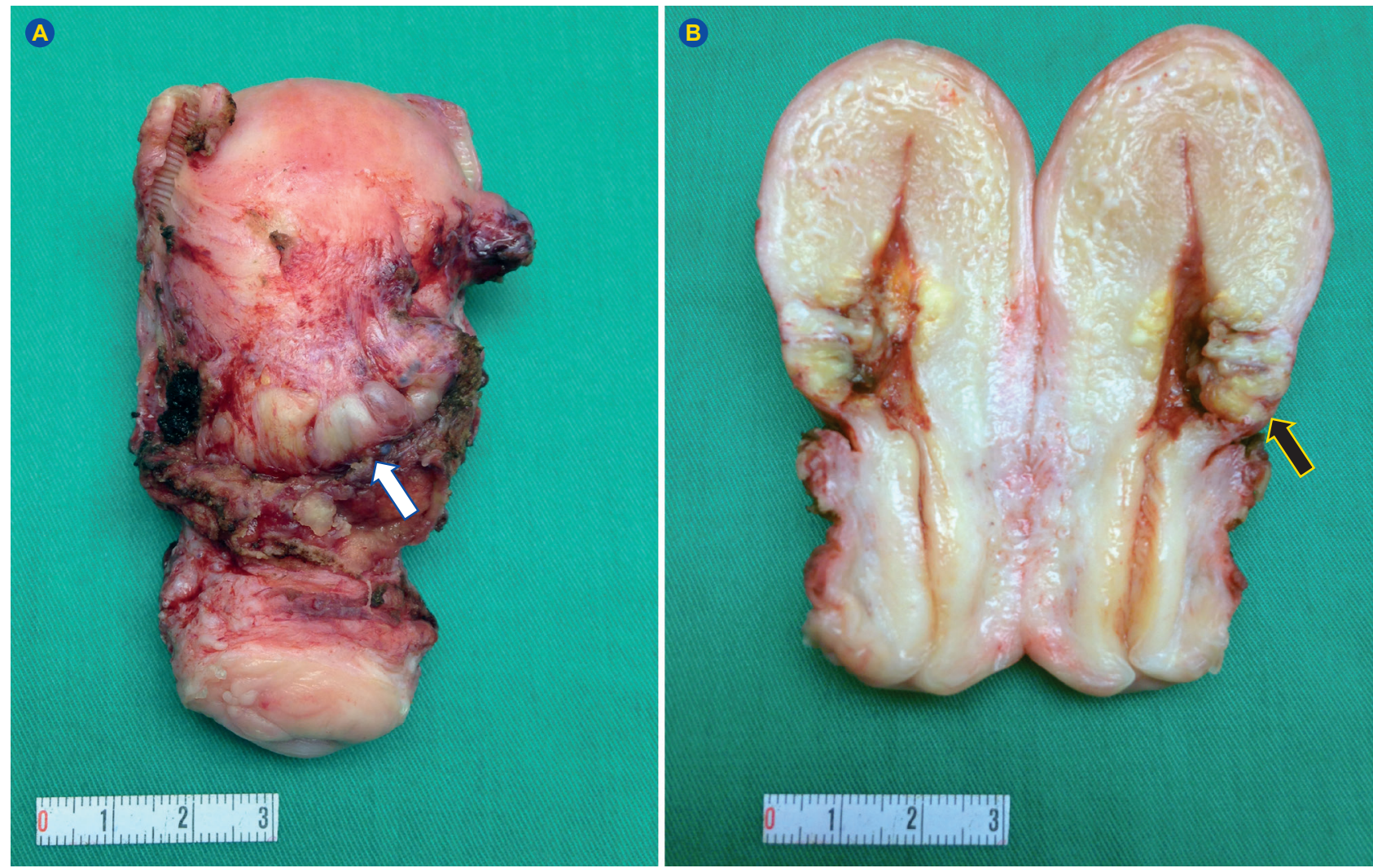

Figure 3 - Macroscopy: (A) Tumor mass with a multilobulated placental like gross appearance (white arrow); (B) dissecting growth pattern towards the serosa (black arrow)

\section{DISCUSSION}

Uterine smooth muscle tumors are known to exhibit a wide variety of growth patterns, with the unusual variants accounting for approximately $10 \%{ }^{3}$ One rare variant is the cotyledonoid dissecting leiomyoma (CDL), initially recognized in 1975 and described by Roth et al in 1996 as a tumor that presents clinically and radiologically as an apparent malignant growth. ${ }^{4}$ The age distribution ranges from 23 to 73 years. ${ }^{5}$ The typical presenting symptoms are abdominal pain, bloating, constipation and weight gain but the most common presentation is abnormal uterine bleeding. ${ }^{5}$

CDL is characterized by an exophytic, lobulated, congested, reddish placenta-like mass, ${ }^{6}$ as was seen in our case. These leiomyomas tend to arise in the subserosal myometrium, with a dissecting pattern adjacent to the dominant mass. ${ }^{1}$

Histologically it is composed of epithelioid to spindle smooth muscle cells growing in sweeping and disorganized fascicles. Immunohistochemically, the cells usually express smooth muscle actin, desmin and h-caldesmon. There is no nuclear atypia or mitosis. ${ }^{6}$ These findings are consistent with those reported by other authors. All cases described to date have been clinically benign. ${ }^{5}$

Its tendency is to expand beyond the pelvic cavity into the abdomen, namely the adnexal organs, as in our patient, the broad ligaments, the larger abdominopelvic cavity, the retroperitoneum, and the surfaces of the uterine cervix and bladder. $^{5}$
A number of variants of CDL have been reported, including cotyledonoid leiomyoma that lacks a detectable intramural component and dissecting leiomyoma that lacks an extrauterine component. ${ }^{7}$ Also, the interpretation of vascular involvement in CDL is controversial. Intravenous leiomyomatosis is characterized by a macroscopically visible vascular lesion or the presence of intravenous proliferations of benign-appearing smooth muscle outside the confines of a leiomyoma. ${ }^{5}$ This particularity was not present in our case.

Other interesting fact is that several reports alluded to CDL with non-neoplastic cyst lesions, such as adenomyosis, ${ }^{3}$ adenoleiomyomatous component, ${ }^{3}$ limited foci of endometriosis ${ }^{8}$ and endosalpingiosis. ${ }^{9}$ These cases suggest that $\mathrm{CDL}$ might have a unique clinical presentation involving parts of benign non-neoplastic cystic lesions.

The most common treatment for this type of tumor to date has been hysterectomy, influenced by its macroscopic appearance. Roth et $a l,{ }^{5}$ Saeki et $a^{\beta}$ and Kim et $a{ }^{10}{ }^{10}$ reported cases where myomectomy with resection of the extrauterine tumor was performed. One of those women, ${ }^{2}$ a year after the surgery, became pregnant naturally. The tumor did not recur during the pregnancy and the patient underwent a cesarean delivery at 37 weeks.

In our case, macroscopically the lesion looked like a placenta accreta, the first suggested diagnosis and the patient did not want to preserve fertility, so total abdominal hysterectomy, bilateral salpingectomy and tumorectomy of the right ovary was the treatment. Nonetheless, because 

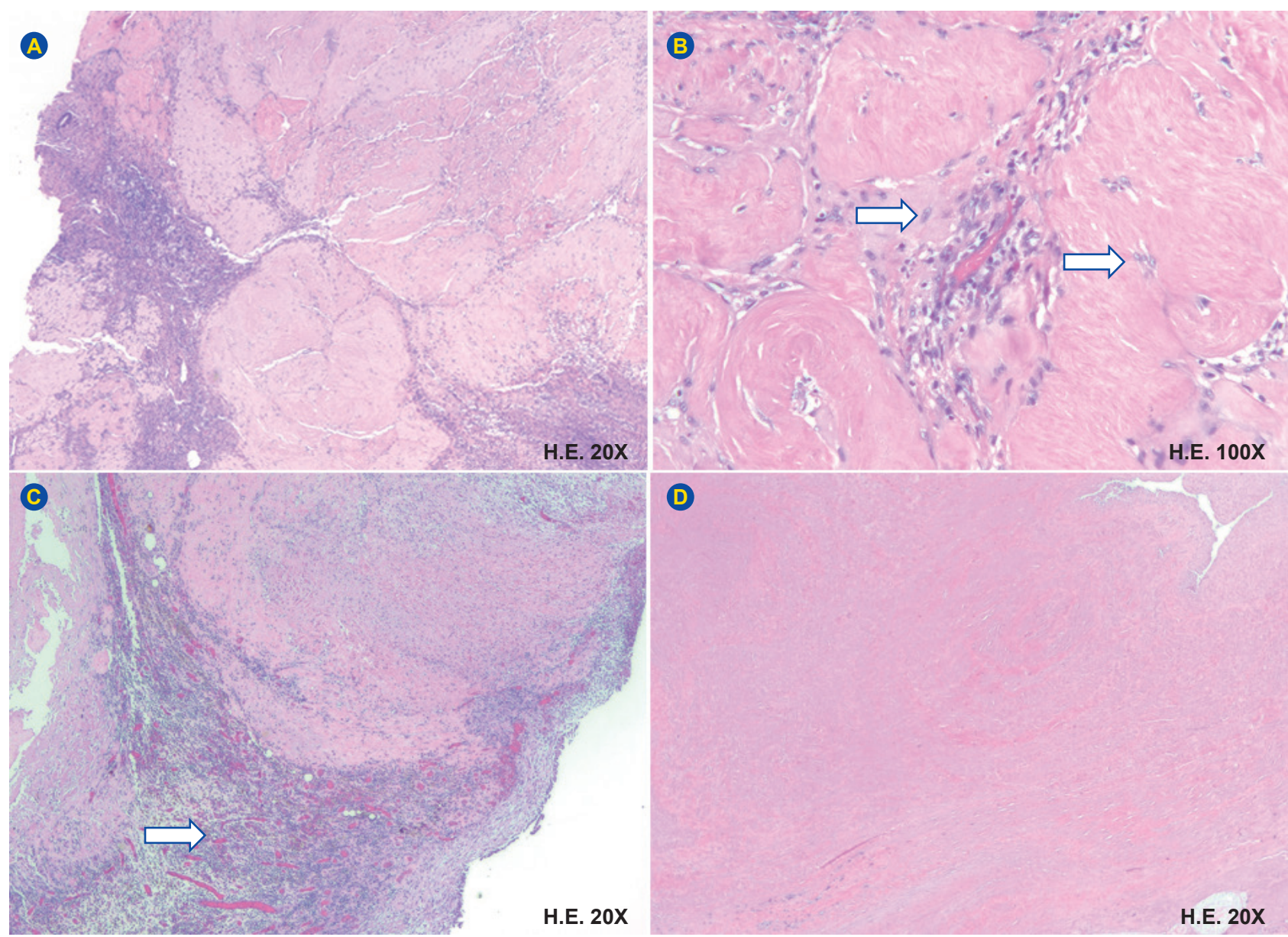

(D)

Figure 4 - Microscopy: Multilobular proliferation of a sparsely cellular hyalinized tissue (A), with foci of granulation tissue (C - arrow) and coagulative necrosis (D); with absence of mitotic figures and atypia (B - arrows)

CDL is fundamentally a benign tumor, it is possible to keep surgery to a minimum without hysterectomy. This type of lesions should undergo frozen section examination to aid the decision about the type of surgery and therefore avoid overtreatment and preserve fertility in younger women.

While recurrence is exceedingly rare, treatment decisions should be informed by the fact that there is a likelihood of recurrence documented after conservative treatment, which the authors attribute to an incomplete excision of the tumor. . $^{5}$ The time for the follow-up is not yet established, depending on several factors, such as the patient age, fertility desires and the surgery performed. Patients in the Roth et all case were followed up until the age of 41 , and none had experienced a recurrence. In our case, the patient has been well without recurrent disease for one and a half years after the surgery.

In summary, CDL is a rare variant of benign leiomyoma, with a bizarre gross appearance that resembles malignant tumors. Differential diagnosis might be problematic without microscopic evaluation. It is important to recognize that this tumor is a benign and unusual variant of leiomyoma, in order to prevent aggressive surgery. This case presentation adds to the literature by documenting the first CDL presenting after delivery, as a differential diagnosis of placenta accreta.

\section{PROTECTION OF HUMANS AND ANIMALS}

The authors declare that the procedures were followed according to the regulations established by the Clinical Research and Ethics Committee and to the Helsinki Declaration of the World Medical Association.

\section{DATA CONFIDENTIALITY}

The authors declare that they followed the protocols in use at their working center regarding patients' data publication.

\section{PATIENT CONSENT}

Obtained.

\section{CONFLICTS OF INTEREST}

The authors declare that there are no conflicts of interest.

\section{FUNDING SOURCES}

No subsidies or grants contributed to this work. 


\section{REFERENCES}

1. Roth LM, Reed RJ, Sternberg WH. Cotyledonoid dissecting leiomyoma of the uterus. The Sternberg tumor. Am J Surg Pathol. 1996;20:145561.

2. Saeki H, Suzuki C. Cotyledonoid dissecting leiomyoma of the uterus: report of two cases. Arch Gynecol Obstet. 2015;291:357-61.

3. Shimizu A, Tanaka H, Iwasaki S. An unusual case of uterine cotyledonoid dissecting leiomyoma with adenomyosis. Diagn Pathol. 2016;11:69.

4. Smith CC, Gold MA, Wile G. Cotyledonoid dissecting leiomyoma of the uterus: a review of clinical, pathological, and radiological features. Int J Surg Pathol. 2012;20:330-41.

5. Roth LM, Kirker JA, Insull M, Whittaker J. Recurrent cotyledonoid dissecting leiomyoma of the uterus. Int J Gynecol Pathol. 2013;32:21520.

6. Bas S, Selcuk, I. Cotyledonoid myoma: a distinct entity and a diagnostic dilemma in gynecology. J Cases Obstet Gynecol. 2015;2:91-3.

7. Roth LM, Reed RJ. Cotyledonoid leiomyoma of the uterus: report of a case. Int J Gynecol Pathol. 2000;19:272-5.

8. Fukunaga M, Ushigome S. Dissecting leiomyoma of the uterus with extrauterine extension. Histopathology. 1997;32:160-4.

9. Driss M, Zhioua F, Doghri R. Cotyledonoid dissecting leiomyoma of the uterus associated with endosalpingiosis. Arch Gynecol Obstet. 2009;280:1063-5.

10. Kim MJ, Park YK, Cho JH. Cotyledonoid dissecting leiomyoma of the uterus: a case report and review of the literature. J Korean Med Sci. 2002;17:840-4.

11. Weissferdt A, Maheshwari MB, Downey GP. Cotyledonoid dissecting leiomyoma of the uterus: a case report. Diagn Pathol. 2007;2:18.

12. Menolascino-Bratta F, Barriola VG. Cotyledonoid dissecting leiomyoma (Sternberg tumor): an unusual form of Leiomyoma. Pathol Res Pract. 1999;195:435-8.

13. Onu D, Fiorentino L, Bunting MW. Cotyledonoid dissecting leiomyoma as a possible cause of chronic lower back pain. BMJ Case Rep. 2013; bcr2013201350.

14. $\mathrm{Xu} \mathrm{T,} \mathrm{Wu} \mathrm{S,} \mathrm{Yang} \mathrm{R.} \mathrm{Cotyledonoid} \mathrm{dissecting} \mathrm{leiomyoma} \mathrm{of} \mathrm{the} \mathrm{uterus:}$ A report of four cases and a review of the literature. Oncol Lett. 2016;11:2865-8

15. Ersoz S, Turgutalp H. Cotyledonoid leiomyoma of uterus: a case report. Turkish J Pathol. 2011;01085

16. Raga F, Cholvi C. More to be learned about cotyledonoid dissecting leiomyoma. Ultrasound Int Open. 2016;2:E73-4

17. Gurbuz A, Karateke A. A case of cotyledonoid leiomyoma and review of the literature. Int J Gynecol Cancer. 2005;15:1218-21.

18. Martinez S, González ML, Lopez RM. Leiomyoma cotiledonoide dissecante del útero. Un tumor benigno de aparência maligna. Ginecol Obstet Mex. 2012;80:528-33.

19. Cheuk W, Chan JC. Cotyledonoid leiomyoma - a benign uterine tumor with alarming gross appearance. Arch Pathol Lab Med. 2002;126:210

20. Preda L, Rizzo S. MRI features of cotyledonoid dissecting leiomyoma of the uterus. Tumori. 2009;95:532-4.

21. Kim J, Park Y. Cotyledonoid dissecting leiomyoma of the uterus: a case report and review of the literature. J Korean Med Sci. 2002;17:840-4 